\title{
Characterization of a serine protease inhibitor from Trichinella spiralis and its participation in larval invasion of host's intestinal epithelial cells
}

\author{
Yan Yan Song, Yao Zhang, Hua Nan Ren, Ge Ge Sun, Xin Qi, Fan Yang, Peng Jiang, Xi Zhang, Jing Cui
} and Zhong Quan Wang*

\begin{abstract}
Background: Trichinella spiralis serine protease inhibitor (TSSPI) was identified in ES proteins of adult worms (AW), the TsSPI gene was highly expressed at enteral stage worms (AW and newborn larvae), distributed mainly in the cuticle and stichosome of this nematode. Vaccination of mice with rTsSPI exhibited a $62.2 \%$ reduction of intestinal AW and a $57.25 \%$ reduction of muscle larvae after larval challenge. The aim of this study was to investigate the biological characteristics of TsSPI and its roles in the process of T. spiralis invasion of host's intestinal epithelium cells (IECS).

Methods: The rTsSPI inhibition on trypsin enzymatic activity was detected by SDS-PAGE and spectrophotometry. The binding of rTSSPI with intestinal epithelium from normal mice and the primary cultured mouse intestinal epithelium cells (IECS) was examined by indirect immunofluorescent (IIF), the cellular localization of rTsSPI binding to IECs was observed by confocal microscopy. The inhibition of anti-rTsSPI serum on T. spiralis invasion of IECS was determined by an in vitro invasion assay. Anti-rTsSPI antibody cytotoxicity on the newborn larvae (NBL) was also determined.

Results: The rTsSPI had the inhibitory activity against porcine trypsin. The rTsSPI specifically bound to the intestinal epithelium from normal mice and primary cultured mouse IECs, and the binding sites were located in IEC membrane and cytoplasm. Anti-rTsSPI antibodies depressed the larval invasion of IECs with a dose-dependent mode. Anti-rTsSPI antibodies also participated in the destruction of T. spiralis NBL via an ADCC-mediated manner.
\end{abstract}

Conclusions: TsSPI might participate in the T. spiralis larval invasion of IECs and it is likely the potential vaccine target against $T$. spiralis enteral stages.

Keywords: Trichinella spiralis, Serine protease inhibitor, Inhibitory activity, Trypsin, Larval invasion

\section{Background}

Trichinellosis is a major zoonotic parasitosis resulted from the ingestion of raw or under-cooked meat infected with the nematodes Trichinella spp. Three classes of vertebrates (mammals, birds and reptiles) are known to act as the hosts of Trichinella spp. and natural infections have been described in more than 150 mammalian species [1], and patients with trichinellosis have been recorded in 55 countries in the world [2]. Trichinella

\footnotetext{
* Correspondence: cuij@zzu.edu.cn; wangzq2015@126.com

Department of Parasitology, Medical College, Zhengzhou University, 40 Daxue Road, Zhengzhou 450052, People's Republic of China
}

spiralis is the main pathogen causing human trichinellosis and the important reservoir host is domestic swine $[3,4]$; porcine meat is the major infectious source of $T$. spiralis infection in humans [5]. Trichinella infection is not only an important public health concern, but also a serious threat to animal food safety. Development of control measures is required to block the transmission of trichinellosis among animals and from animals to humans [6].

When the contaminated meat is ingested by hosts, $T$. spiralis muscle larvae (ML) are liberated in stomach under the action of digestive enzymes, migrate to the

(c) The Author(s). 2018 Open Access This article is distributed under the terms of the Creative Commons Attribution 4.0 International License (http://creativecommons.org/licenses/by/4.0/), which permits unrestricted use, distribution, and 
small intestine, and develop into intestinal first-stage infective larvae (IL1) [7, 8]. The IL1 invade intestinal epithelium cells (IECs) where they develop into female/ male adult worms (AW) after undergoing four molts within $31 \mathrm{~h}$. About 5 days post-infection (dpi), the ovoviviparous females release the newborn larvae (NBL) that penetrate into skeletal muscles, where they encapsulate and elicit the formation of nurse cell-muscle larva complex [8]. Intestinal mucosa is the first native barrier against Trichinella infection and the principal interaction site between intestinal parasites and the host [9, 10]. The encapsulated ML may survive for several years in living hosts without any major harm [11], but the mechanism of immune evasion of this parasite is not fully known. Theoretically, the prevention and control of Trichinella infection should be to interrupt the IL1 lodge in IECs, to block larval development to AW and NBL production, to interdict NBL migration and to eliminate AW and NBL from the gut [12].

Serine protease inhibitors (serpins) is a superfamily of conserved proteins which inhibit serine protease activity and act a pivotal part in inflammation, and fibrinolysis [13]. The helminth-secreted serpins protect the parasites from host's serine proteolysis, help the worms to invade the defensive barriers, and to escape the host's immune attack [14]. A T. spiralis serpin from the ML (GenBank: AF231948) has been identified and expressed. This recombinant protein inhibits trypsin activity [15]. Two serpins from $T$. spiralis inhibited the activities of chymotrypsin and pepsin [16]. Another serpin screened from T. spiralis ML cDNA library was expressed, and vaccination of mice with rTs-serpin exhibited partial protection against Trichinella larval challenge [17].

Previous studies showed a $T$. spiralis serine protease inhibitor (TsSPI, GenBank: XP_003377380.1) identified in the T. spiralis AW excretory/secretory (ES) proteins by immunoproteomics with early infection sera $[10$, 18]. Bioinformatics analysis revealed that the complete TsSPI cDNA sequence was $1050 \mathrm{bp}$, encoded a 39.6 $\mathrm{kDa}$ protein of 349 amino acids. The SMART analysis showed that there was a functional domain with an active site containing the classic reactive central loop (RCL) of serine protease inhibitors. The TsSPI gene was cloned and expressed in our labarotory. Quantitative PCR (qPCR) and immunofluorescence assay revealed that the TsSPI gene was highly expressed at enteral stage worms (AW and NBL), principally located in the cuticle and stichosome of this nematode. Vaccination of mice with rTsSPI produced a $62.2 \%$ intestinal AW reduction and a 57.25\% ML reduction after larval challenge [19]. The aim of this study was to investigate the biological characteristics of TsSPI and its roles in the course of T. spiralis invasion of host's IECs.

\section{Methods \\ Mice and parasites}

Female BALB/c mice, 6 weeks old, were obtained from the Zhengzhou University Experimental Animal Center (Zhengzhou, China). Trichinella spiralis strain (ISS534) was collected from a domestic porcine in Henan Province of China. We kept this strain by passage in mice every 6 months.

\section{Collection of worms at various stages}

Mice were infected orally with $300 \mathrm{~T}$. spiralis larvae and the ML were acquired by artificial digestion of infected mouse carcasses at 42 days post-infection (dpi) $[20,21]$. The IL1 were isolated from intestine at $6 \mathrm{~h}$ post-infection [22], and the AW were obtained from intestine at $6 \mathrm{dpi}$ [23]. The $6 \mathrm{dpi}$ female adults were cultured for $24 \mathrm{~h}$ at $37{ }^{\circ} \mathrm{C}$ for recovering newborn larvae (NBL) [24]. The IL1 excretory-secretory (ES) proteins were prepared [25].

\section{Cell culture and protein preparation}

The primary IECs were prepared from fetal mouse intestines and susceptible to T. spiralis invasion [7]. The mouse striated muscle myoblast $\mathrm{C} 2 \mathrm{C} 12$ was unsusceptible to the larval invasion and utilized as negative control [26]. The cells were cultivated by using Dulbecco's modified Eagle's medium and recovered following trypsinization. The IEC lysates were prepared with the help of grinding, sonicating and centrifuging as described [27]. The concentration of IEC and IL1 ES proteins was measured by the Bradford assay [28].

\section{The rTsSPI and anti-rTsSPI serum}

The TsSPI gene was cloned, and the recombinant pQE-80L/TsSPI was transformed into Escherichia coli BL21 (DE3) (Novagen, La Jolla, CA, USA) [29]. The TsSPI was induced with $0.5 \mathrm{mM}$ IPTG at $37^{\circ} \mathrm{C}$ for $5 \mathrm{~h}$, and then purified by using a Ni-NTA His-tag affinity kit (Novagen) in our laboratory [19]. Ten mice were subcutaneously immunized with $20 \mu \mathrm{g}$ of the rTsSPI emulsified with complete Freund's adjuvant, and boosted 3 times with the rTsSPI with incomplete Freund's adjuvant at two weeks interval $[30,31]$. Anti-rTsSPI immune serum were collected at two weeks following the fourth immunization, and pre-immune normal serum was used as negative control [32].

\section{SDS-PAGE analysis of rTsSPI activity for inhibiting trypsin}

In order to observe the rTsSPI inhibiting effect on trypsin hydrolysis of BSA, $0.5 \mu \mathrm{g}$ of trypsin and different concentration of rTsSPI $(3-6 \mu \mathrm{g})$ and BSA $(0.75-4.5 \mu \mathrm{g})$ was used in SDS-PAGE analysis with 5\% stacking gels and $12 \%$ resolving gels, and stained with Coomassie brilliant blue R-250 [33]. rTsSPI was pre-incubated with 
trypsin in $20 \mu \mathrm{l}$ of PBS for $30 \mathrm{~min}$ at $37^{\circ} \mathrm{C}$. Following centrifugation at $5000 \times g$ for $10 \mathrm{~s}$, BSA was added and reacted for $1 \mathrm{~h}$ at $37^{\circ} \mathrm{C}$. The mixture of trypsin and BSA was used as positive control; negative control contained trypsin alone or rTsSPI only. Reactions were ceased by the addition of sample buffer contained 2\% SDS and 1\% $\beta$-mercaptoethanol. Samples were denatured at $100{ }^{\circ} \mathrm{C}$ for $5 \mathrm{~min}$ and separated on $12 \%$ gels $[34,35]$.

\section{Spectrophotometric assay of rTsSPI activity for inhibiting trypsin}

The rTsSPI $(0-18 \mu \mathrm{g})$ was firstly pre-incubated with tryp$\sin (1.25 \mu \mathrm{g})$ in $20 \mu \mathrm{l}$ of PBS for $30 \mathrm{~min}$ at $37^{\circ} \mathrm{C}$, subsequently added $100 \mu \mathrm{l}$ of $0.5 \mathrm{mM}$ N-Benzoyl-DL-arginine ethyl ester hydrochloride (BAEE; BBI, BBI CO., LTD, Shanghai, China). Under this reaction conditions, trypsin substrate BAEE was converted to N-Benzoyl-DL-arginine (BA) within $5 \mathrm{~min}$. Catalytic substrate reaction occurs every minute, and the enzyme required for every 0.001 increase in absorbance at A253 $\mathrm{nm}$ is an enzyme activity unit [36]. Each sample had three replicates. The absorbance at $253 \mathrm{~nm}$ was measured by a spectrophotometer (Mapada, Shanghai, China). The inhibition rate was calculated as follows:

$$
\begin{aligned}
\text { Inhibition rate }(\%)= & {[\text { (Total enzyme activity units }} \\
& \text { - Residual enzyme activity units }) \\
& / \text { Total enzyme activity units }] \times 100
\end{aligned}
$$

\section{Effect of temperature and $\mathrm{pH}$ on stability of rTsSPI activity for inhibiting trypsin}

The rTsSPI $(1.5 \mu \mathrm{g} / \mu \mathrm{l}, 100 \mathrm{mM}$ Tris- $\mathrm{HCl}, \mathrm{pH}$ 8.0) was heated at $30-100{ }^{\circ} \mathrm{C}$ for $30 \mathrm{~min}$, subsequently cooled at room temperature, and residual enzymatic activity of trypsin was measured. To assay the $\mathrm{pH}$ stability, the rTsSPI solution $(1.5 \mu \mathrm{g} / \mu \mathrm{l})$ was diluted with an equal volume of $100 \mathrm{mM}$ different buffers: sodium citrate, $\mathrm{pH}$ 2-4; sodium acetate, $\mathrm{pH} 4.5-5.5$; sodium phosphate, $\mathrm{pH}$ 6.0-7.0; Tris- $\mathrm{HCl}, \mathrm{pH}$ 7.5-8.5; and sodium bicarbonate, $\mathrm{pH}$ 9.0-10.0. After being incubated in each buffer at $37^{\circ}$ $\mathrm{C}$ for $30 \mathrm{~min}$, the $\mathrm{pH}$ was modulated to $\mathrm{pH} 8.0$, and the rTsSPI inhibitory activity against trypsin was measured as described in [37].

After the above treatment, the residual inhibitory activity of the rTsSPI on trypsin was assayed using BAEE as substrate. Aliquots $(1.5 \mu \mathrm{g} / \mu \mathrm{l}, 12 \mu \mathrm{l}$ of $\mathrm{rTsSPI})$ were mixed with a swine trypsin $(5 \mu \mathrm{l}, 0.25 \mu \mathrm{g} / \mu \mathrm{l}$ in $0.1 \mathrm{mM}$ $\mathrm{HCl})$ in $50 \mathrm{mM}$ Tris- $\mathrm{HCl}, \mathrm{pH}$ 8.0. The mixture was incubated at $37{ }^{\circ} \mathrm{C}$ for $30 \mathrm{~min}$, and then $100 \mu \mathrm{l}$ of 0.5 mM BAEE were added to make a final volume of $120 \mu$ l. The absorbance at $253 \mathrm{~nm}$ was measured as above described. All samples were tested in triplicate and the data are expressed as the mean \pm standard deviation (SD) of the triplicate.

\section{Far Western analysis of rTsSPI binding with IECs}

On Far Western analysis of protein interaction between rTsSPI and IECs, the protein samples of IECs were separated by SDS-PAGE analysis [27, 38, 39]. The gel was transferred onto the nitrocellulose membrane (Merck Millipore, Billerica, MA, USA) at $80 \mathrm{~V}$ for $40 \mathrm{~min}$ in a semi-dry transfer cell (Bio-Rad, Hercules, CA, USA) [11]. The membrane was cut and blocked with $5 \%$ skim milk in PBS-0.5\% Tween 20 (PBST) for $2 \mathrm{~h}$ at $37{ }^{\circ} \mathrm{C}$, subsequently incubated $\left(37{ }^{\circ} \mathrm{C}, 2 \mathrm{~h}\right)$ with $20 \mu \mathrm{g} / \mathrm{ml}$ rTsSPI, and the IL1 ES proteins and bovine serum albumin (BSA) were used as control groups [39]. After washing, the strips were incubated $\left(37^{\circ} \mathrm{C}, 2 \mathrm{~h}\right)$ with $1: 100$ dilutions of different sera (anti-rTsSPI serum, infection serum or pre-immune serum). After washing, the strips were incubated for $1 \mathrm{~h}$ at $37^{\circ} \mathrm{C}$ with 1:10,000 dilutions of anti-mouse IgG-HRP-conjugate, and colored by using DAB (Sigma-Aldrich, St. Louis, MO, USA) [40]. The IEC protein bands bound to rTsSPI were analyzed with the Alpha view Software (AIC, http://alphaview-sa1.software.informer.com) [41].

\section{Indirect immunofluorescent (IIF) analysis of rTsSPI binding with IEC and cellular localization}

The IECs and C2C12 cells were grown to about 90\% confluence on glass coverslips in DMEM medium in culture plates for $36 \mathrm{~h}$ [42]. The viable cell monolayer was incubated for $2 \mathrm{~h}$ at $37^{\circ} \mathrm{C}$ with $20 \mu \mathrm{g} / \mathrm{ml}$ rTsSPI. The IL1 ES protein and PBS were utilized as a positive and negative control, respectively. After washing, the monolayer was fixed with $4 \%$ formaldehyde for $20 \mathrm{~min}$. The monolayer was incubated with 1:10 dilutions of infection serum, anti-rTsSPI serum or pre-immune serum, subsequently incubated with 1:100 dilutions of anti-mouse IgG-FITC conjugate (Santa Cruz, Biotechnology, Dallas, Texas, USA) at $37^{\circ} \mathrm{C}$ for $1 \mathrm{~h}$. The monolayer cell nuclei were dyed with propidium iodide (PI). After being washed again, the cells were observed with the aid of fluorescent microscopy (Olympus, Tokyo, Japan) [43]. Furthermore, the cellular localization of rTsSPI within IECs was further examined with a laser scanning confocal microscopy [39].

IIF analysis of binding of rTsSPI with intestinal epithelium Small intestines and livers were obtained from uninfected mice, fixed in $4 \%$ formaldehyde and $3-\mu \mathrm{m} \mathrm{sec}-$ tions were prepared with a microtome. The IIF was performed as reported with some modifications [39, 44]. Briefly, the tissue sections were respectively incubated with 1:10 dilution of anti-rTsSPI serum, infection serum or normal serum for $2 \mathrm{~h}$ at $37{ }^{\circ} \mathrm{C}$. After washing, the 
sections were incubated with anti-mouse IgG-FITC conjugate (1:100; Santa Cruz, USA). The intestinal epithelium cell nuclei were stained with PI. Finally, the sections were observed using fluorescent microscopy (Olympus) [45].

\section{The in vitro larval invasion of IECs}

To evaluate the inhibitive effects of anti-rTsSPI serum on the IEC invasion by $T$. spiralis, the activated ML was utilized in the invasion test. The ML were activated into the IL1 by $5 \%$ mouse bile for $2 \mathrm{~h}$ at $37{ }^{\circ} \mathrm{C}[9,46]$. Two hundred larvae were added into semisolid culture media (serum-free DMEM with $15 \mathrm{mM}$ HEPES and 1.75\% agarose), which were used to overlay the IEC monolayer. The media were supplemented with anti-rTsSPI serum (1:100 to $1: 1600)$, or infection serum or pre-immune serum diluted at 1:100 [26]. After incubation at $37^{\circ} \mathrm{C}$ for $2 \mathrm{~h}$, the larvae penetrated into the monolayer were numbered under microscopy. The larvae invaded and migrated into the monolayer were counted as invaded larvae, whereas the larvae suspended in the media were counted as non-invaded larvae $[47,48]$. Three independent tests for three groups of serum samples were carried out and three repeats were used to determine the larval invasion for each kind of serum.

\section{Antibody-dependent cell-mediated cytotoxicity (ADCC) assay}

Anti-rTsSPI antibody cytotoxicity on $T$. spiralis NBL was determined $[49,50]$. Infection serum and pre-immune serum were utilized as positive and negative control, respectively. Peritoneal exudates cells (PECs) were collected from peritoneal exudate of normal mice after intraperitoneal injection with $4.5 \mathrm{ml}$ of sterile RPMI-1640 medium (Gibco, Waltham, USA). After five days, peritoneal cavity was washed with RPMI-1640. The cellular suspension was centrifuged at $1500 \times g$ for 10 min. The number of PECs was estimated in a cell counter. The cell suspensions contained $2.5 \times 10^{6}$ cells $/ \mathrm{ml}$. Mouse sera were diluted to $1: 50$ to $1: 800$ with RPMI 1640 medium, and added to the $200 \mu \mathrm{l}$ suspension contained $100 \mathrm{NBL}$ and $1 \times 10^{5}$ PECs. The suspension was incubated in a 96 -well culture plate $5 \% \mathrm{CO}_{2}$ at $37{ }^{\circ} \mathrm{C}$ for $72 \mathrm{~h}$. Each assay was performed in triplicate. The larval viability treated by ADCC was estimated on the basis of their morphology and activity under microscope. The living NBL are mobile and show wriggling motion, while the dead worms are straight, inactive or disintegrated [45, 51]. The result was expressed as the percentage of dead NBL to the total number of NBL used for each assay.

\section{Statistical analysis}

The data were statistically analyzed using the SPSS 17.0 software. The data were shown as the mean \pm standard deviation (SD). Chi-square tests or one-way ANOVAs were utilized to analyze the differences between different groups. Spearman's rank correlation ( $r$ ) was used to analyze the TsSPI inhibitory activity against trypsin. $P<0.05$ was considered as statistically significant.

\section{Results}

Inhibition of trypsin hydrolysis of BSA by rTsSPI

SDS-PAGE analysis revealed that $0.50 \mu \mathrm{g}$ trypsin could degrade different concentrations of BSA $(0.75-4.50 \mu \mathrm{g})$ (Fig. 1a) and rTsSPI (3.00-6.75 $\mu \mathrm{g}$ ) (Fig. 1b); the trypsin hydrolysis of BSA could be inhibited by rTsSPI (6.00$6.75 \mu \mathrm{g}$ ) (Fig. 1c). The proteolytic activity of trypsin was also inhibited by natural inhibitor phenylmethylsulfonyl fluoride (PMSF) (Fig. 1d).

\section{rTsSPI inhibitory function on trypsin activity determined by spectrophotometry}

The rTsSPI inhibitory activity on trypsin was determined at various concentrations of the substrate BAEE. The results revealed that the trypsin enzymatic activity was inhibited with rTsSPI. The inhibition rate was $80.64 \%$ and the inhibition was rTsSPI dose-dependent $\left(r_{(12)}=\right.$ 0.990, $P<0.001$ ) (Fig. 2).

\section{Stability of rTsSPI activity for inhibiting trypsin}

The results of temperature effects on rTsSPI inhibitory activity revealed that the inhibitory rate of rTsSPI on trypsin was $80.97 \%$ at $37{ }^{\circ} \mathrm{C}$, and exhibited a trend of decrease with temperature increase decreasing to $66.67 \%$ at $100{ }^{\circ} \mathrm{C}$ (Fig. 3a) thus indicating that TsSPI could maintain its inhibitory activity within a temperature range of $37-100{ }^{\circ} \mathrm{C}$. Pre-incubation of the rTsSPI at $\mathrm{pH}$ 2.0-10.0 for $30 \mathrm{~min}$ did not affect noticeably the inhibitory effect of rTsSPI on trypsin (Fig. 3b).

\section{Far Western analysis of rTsSPI binding to IECs}

The IEC lysates were analyzed using SDS-PAGE (Fig. 4a). The results showed about 29 protein bands with a molecular weight of $14.8-95 \mathrm{kDa}$ in IEC lysates. Far Western analysis revealed that after incubation with the rTsSPI, all these protein bands from IEC lysates were recognized by anti-rTsSPI serum; of these, about 8 bands $(16.6-58.1 \mathrm{kDa})$ were recognized by the infection serum, but no protein bands were recognized by the pre-immune serum (Fig. 4b). After IEC proteins were incubated with the IL1 ES antigens, anti-rTsSPI serum recognized 4 bands (97.2, 72.3, 66.0 and $55.7 \mathrm{kDa}$ ) of IEC proteins, infection serum recognized about 9 bands (37.7-97.2 kDa), and pre-immune serum did not recognize any bands of IEC proteins. No binding between $\mathrm{C} 2 \mathrm{C} 12$ proteins and rTsSPI was observed by either anti-rTsSPI serum or infection serum. The results indicated that there was a specific binding and interaction between IEC and rTsSPI. 
a

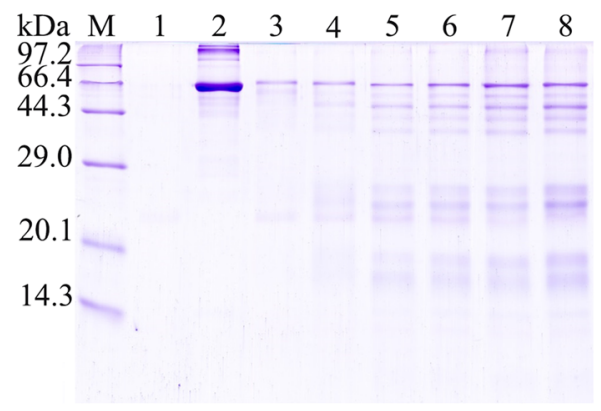

c

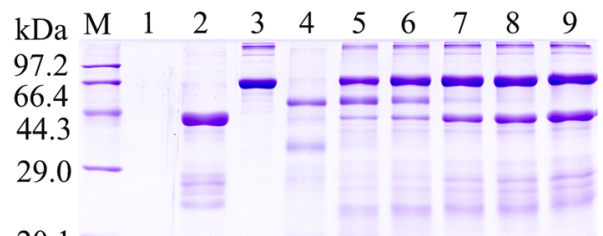

$20.1-$

14.3 b

$\begin{array}{llllllllll}\mathrm{kDa} & \mathrm{M} & 1 & 2 & 3 & 4 & 5 & 6 & 7 & 8\end{array}$

$97.2=$

44.3 -

$29.0-$

20.1

14.3

d

$\begin{array}{lllllllll}\mathrm{kDa} & \mathrm{M} & 1 & 2 & 3 & 4 & 5 & 6 & 7\end{array}$

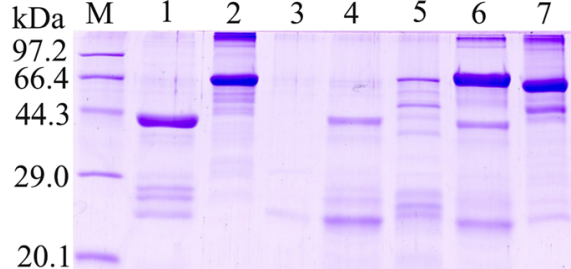

20.1

14.3

Fig. 1 SDS-PAGE analysis of rTSSPI activity for inhibiting trypsin hydrolysis of BSA. a Different quantity of BSA were hydrolyzed by trypsin. Lane M: protein marker; Lane 1: trypsin; Lane 2: BSA; Lanes 3-8: trypsin + BSA $(0.75,1.50,2.25,3.00,3.75$ and $4.50 \mu \mathrm{g}$, respectively). b Different quantity of rTsSPI were hydrolyzed by trypsin. Lane M: protein marker; Lane 1: trypsin; Lane 2: rTsSPI; Lanes 3-8: trypsin + rTsSPI (3.00, 3.75, 4.50, 5.25, 6.00 and $6.75 \mu \mathrm{g}$, respectively). c The trypsin hydrolysis of BSA was inhibited by different quantity of rTsSPI. Lane M: protein marker; Lane 1: trypsin; Lane 2: rTsSPI; Lane 3: BSA; Lanes 4-9: trypsin + BSA + rTsSPI (3.00, 3.75, 4.50, 5.25, 6.00 and $6.75 \mu \mathrm{g}$, respectively). d The trypsin hydrolysis of BSA was inhibited by rTsSPI and natural inhibitor PMSF. Lane M: protein marker; Lane 1: TsSPI; Lane 2: BSA; Lane 3: trypsin; Lane 4: trypsin + rTsSPI; Lane 5: trypsin+BSA; Lane 6: rTsSPI+trypsin+BSA; Lane 7: PMSF+trypsin+BSA

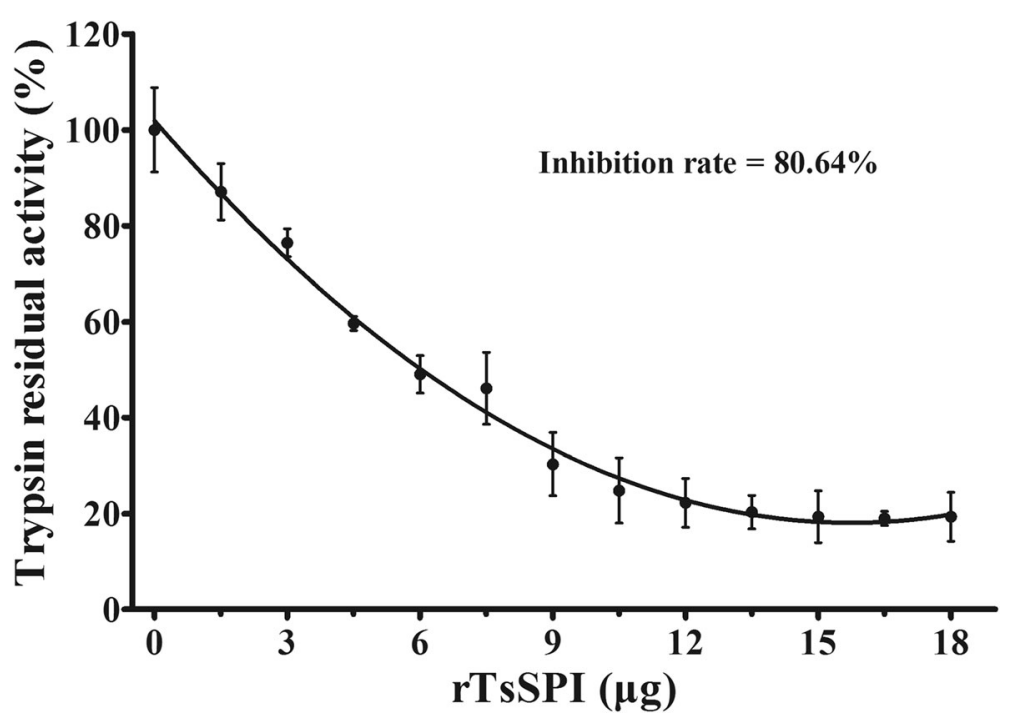

Fig. 2 The titration curve graph of trypsin activity inhibited by rTsSPI. rTsSPI of different quantity was added to a fixed quantity of trypsin (1.25 $\mu \mathrm{g})$. The absorbance at $253 \mathrm{~nm}$ was measured by spectrophotometry with the substrate BAEE, and the inhibition rate of trypsin enzymatic activity was calculated as described in method section. Each point is the mean of triplicates 

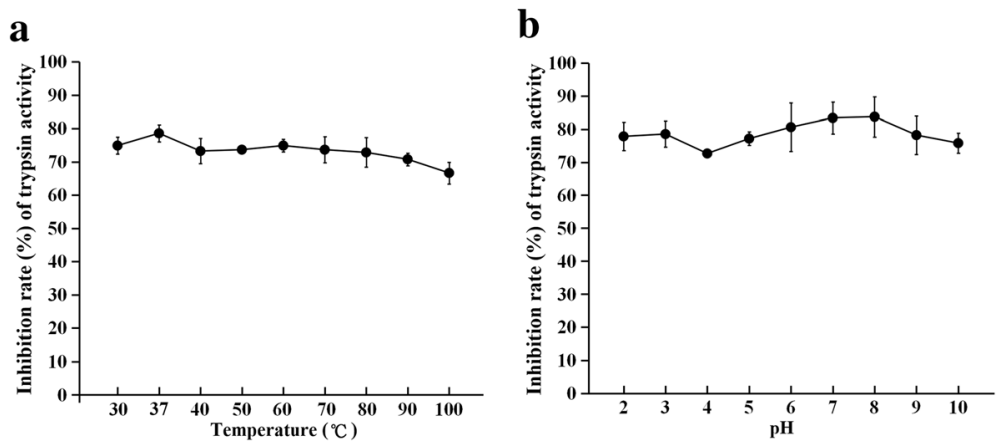

Fig. 3 Stability of rTsSPI activity for inhibiting trypsin after incubation at $37{ }^{\circ} \mathrm{C}$ for $30 \mathrm{~min}$. a Stability of rTsSPI inhibiting activity at different temperature. $\mathbf{b}$ Stability of rTsSPI inhibiting activity at different $\mathrm{pH}$. The residual enzymatic activity of trypsin was determined with BAEE as a substrate. The experiment was performed in triplicate and the data are the mean \pm SD of three tests

\section{IIF analysis of binding of rTsSPI with IEC}

After the IEC was pre-incubated with rTsSPI or IL1 ES proteins, immunostaining was observed on IEC surface probed by anti-rTsSPI serum or infection serum, not by pre-immune serum (Fig. 5). Nevertheless, no fluorescent staining on $\mathrm{C} 2 \mathrm{C} 12$ pre-incubated with rTsSPI was found by either anti-rTsSPI serum or infection serum. When the positive staining IECs were examined by confocal microscopy, the staining was located on IEC cytomembrane and cytoplasm, indicating that rTsSPI could specifically bind to the IEC membrane and pass into cytoplasm (Fig. 6).

\section{Specific binding of rTsSPI with intestinal epithelium detected by IIF}

The results of IIF with intestinal and liver sections revealed that after incubation with rTsSPI, immunostaining on intestinal epithelium was detected by using anti-rTsSPI serum; weak staining was also detected with infection serum (Fig. 7) but no staining was observed with pre-immune serum. Moreover, no fluorescent staining in liver tissues incubated with rTsSPI was detected by either anti-rTsSPI serum or infection serum.

\section{Inhibiting effects of anti-rTsSPI serum on the IEC invasion by $T$. spiralis}

When the IEC monolayer was covered by semisolid media containing the larvae, and cultured for $2 \mathrm{~h}$, the larvae invaded and migrated in the IEC monolayer (Fig. 8a). When 1:100 dilution of anti-rTsSPI serum, infection serum and pre-immune serum were added into the media and cultured for $2 \mathrm{~h}$, the invaded larvae in the monolayer represented $38.7 \%, 16.85 \%$ and $80.08 \%$, respectively, of the

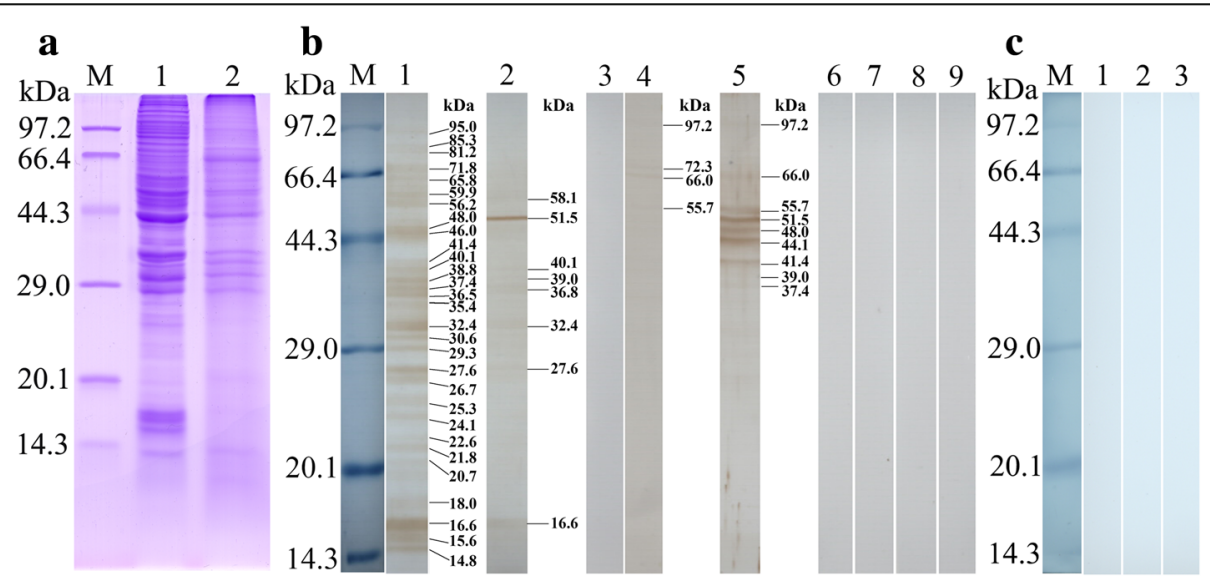

Fig. 4 Far Western analysis of rTsSPI binding to IEC proteins. The IEC proteins were analyzed by SDS-PAGE, subsequently the IEC protein binding with rTsSPI was detected in a Far Western analysis. a SDS-PAGE analysis of IEC proteins. Lane M: protein marker; Lane 1: IEC lysates; Lane 2: C2C12 Iysates. b Far-Western analysis of IEC protein binding to rTsSPI. The IEC protein was first incubated using rTsSPI (Lanes 1-3), IL1 ES proteins (Lanes 4-6) or BSA (Lanes 7-9), subsequently recognized by anti-rTsSPI serum (Lanes 1, 4 and 7), infection serum (Lanes 2, 5 and 8), and pre-immune normal serum (Lanes 3, 6 and 9). c Far Western analysis of C2C12 protein binding to rTsSPI. The C2C12 protein (Lanes 1-3) was first incubated with rTsSPI, and subsequently incubated with anti-rTsSPI serum (Lane 1), infection serum (Lane 2) or pre-immune serum (Lane 3). There was no binding between rTsSPI and the $\mathrm{C} 2 \mathrm{C} 12$ protein 


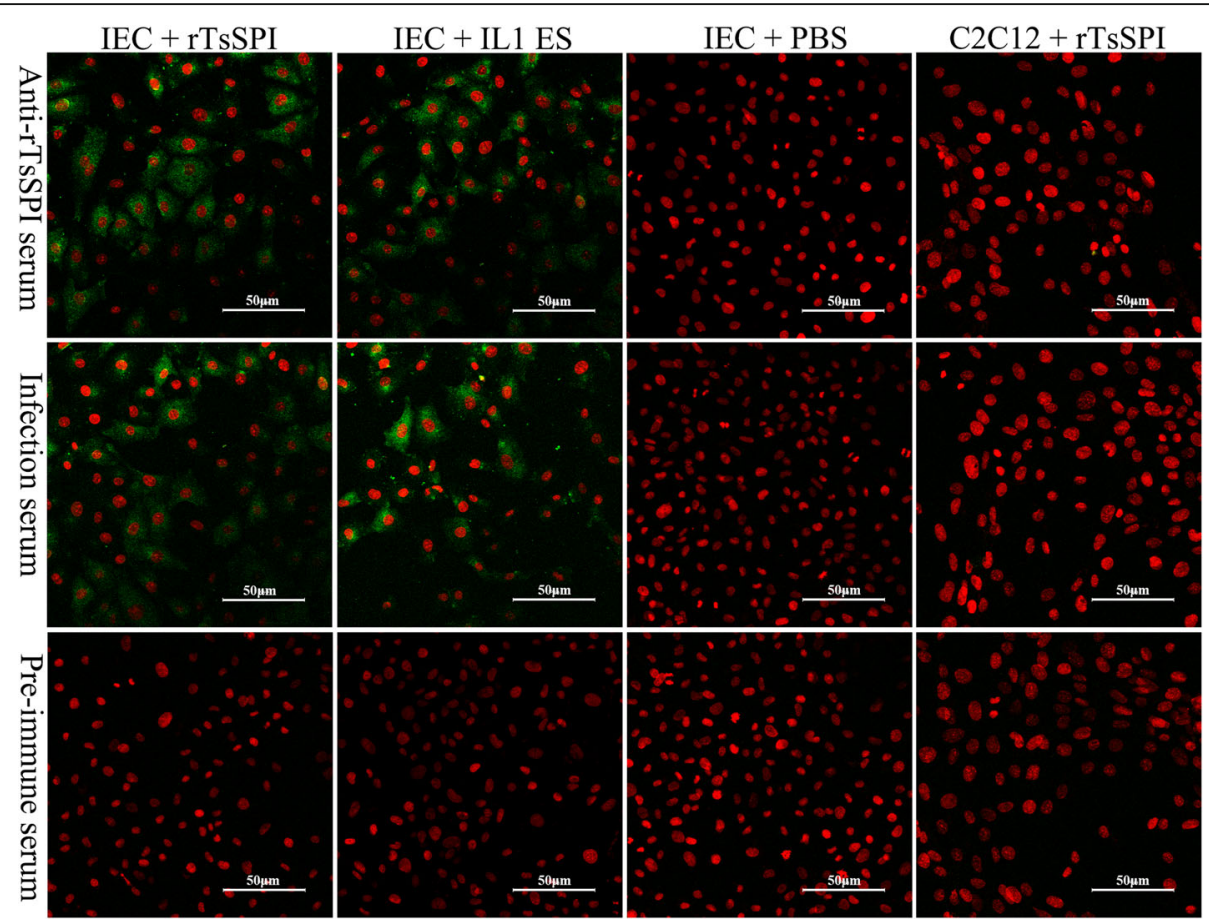

Fig. 5 IIF analysis of binding between rTsSPI and IECS (× 200). rTsSPI, IL1 ES antigens or PBS were used for pre-incubating with IEC for $2 \mathrm{~h}$ at $37^{\circ} \mathrm{C}$. rTsSPI was also pre-incubated with $\mathrm{C} 2 \mathrm{C} 12$ for $2 \mathrm{~h}$ at $37^{\circ} \mathrm{C}$. After washes, the pre-incubated IEC and C2C12 was probed by anti-rTsSPI serum, infection serum or pre-immune serum, subsequently colored with goat anti-mouse IgG-FITC conjugate. Propidium iodide (PI) dyed cell nuclei in red

three groups of sera the difference of larval invasion rate was statistically significant $\left(\chi_{(2)}^{2}=134.354, P<0.001\right)$. The inhibiting effect of the anti-rTsSPI serum on the monolayer invasion was more obvious than those of the pre-immune serum $\left(\chi_{(1)}^{2}=260.000, P<0.001\right)$, and the inhibition was anti-rTsSPI antibody dose-dependent and exhibited a reducing trend with serum dilution elevating $\left(F_{(4,11)}=160.236, P<0.001\right)$ (Fig. 8b) Nonetheless, no apparent inhibition by the pre-immune serum on larval invasion was observed.

\section{ADCC mediated the killing of NBL}

The ADCC test revealed that after incubation, anti-rTsSPI serum could mediate the adhering and killing of the PECs to the NBL (Fig. 9). When anti-rTsSPI serum (1:100 dilution) was incubated for $72 \mathrm{~h}$ with the NBL and PECs, the ADCC resulted in a visible death of NBL (27.67\% cytotoxicity), in comparison to the NBL incubated with pre-immune serum $\left(10.33 \%, X_{(2)}^{2}=10.526, P=0.01\right)$. The cytotoxicity also had an obvious correlation with culture time $\left(r_{(5)}=0.968, P<0.001\right)$, and exhibited an increasing trend with extension of culture time $\left(F_{(5,13)}=117.584\right.$, $P<0.001)$. The cytotoxicity was anti-rTsSPI antibody dose-dependent $\left(r_{(5)}=0.984, P<0.001\right)$, and had a decreasing trend following the increase of serum dilutions $\left(F_{(4,11)}=96.813, P<0.001\right)$ (Fig. 9).

\section{Discussion}

In this study, the TsSPI from T. spiralis adult worms was cloned and expressed. SDS-PAGE analysis and spectrophotometry showed that the rTsSPI reacted strongly with porcine trypsin, had inhibitory activities against porcine trypsin, and the inhibition was rTsSPI dosedependent, demonstrating that trypsin may be the possible target of the inhibitor [16]. The TsSPI could maintain its inhibitory activity against trypsin within a temperature range of $37-100{ }^{\circ} \mathrm{C}$, and $\mathrm{pH}$ values of $2.0-$ 10.0 did not affect noticeably the inhibition effect of rTsSPI on trypsin. However, the precise role that the inhibitor might play in T. spiralis invasion and survival in host's intestine is not completely clear. A hookworm Ancylostoma duodenale adult serpin (AduTIL-1) has been expressed, being distributed in cuticle surface, oesophagus and intestines of adult worms; this rAduTIL-1 was found to show inhibitory activity against human neutrophil elastase and pancreatic trypsin. AduTIL-1 may participate in Ancylostoma survival in host by targeting relative digestive enzymes and elastase [52]. A Schistosoma haematobium serpin was located on the surface of this schistosome and can interact with host cells and proteases [53]. Previous studies showed that the TsSPI was detected in excretory/secretory (ES) proteins of Trichinella spiralis AW, widely distributed on the external surface of AW and NBL cuticle [19]. A T. pseudospiralis serpin is an exocrine 

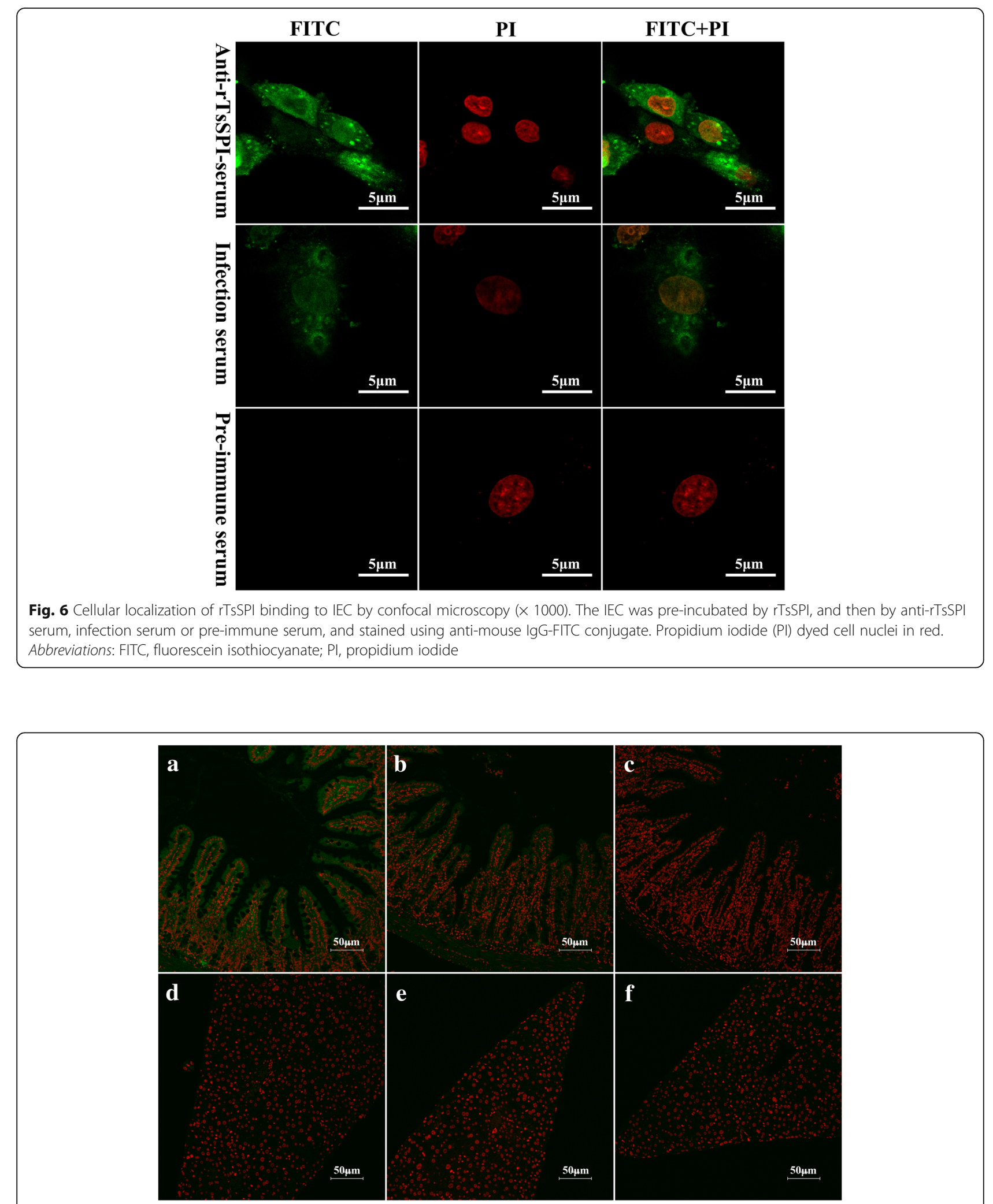

Fig. 7 IIF analysis of rTsSPI binding with mouse intestinal epithelium (100x). Tissue sections of the intestines (a-c) and livers (e-f) from uninfected mice were incubated with rTsSPI for $2 \mathrm{~h}$ at $37{ }^{\circ} \mathrm{C}$. After washing, the sections were probed for $1 \mathrm{~h}$ at $37{ }^{\circ} \mathrm{C}$ with anti-rTsSPI serum (a, d), infection serum (b, e) or pre-immune serum (c, $\mathbf{f}$ ), and then with anti-mouse IgG-FITC conjugate. Propidium iodide (PI) dyed cell nuclei in red. These sections were examined by fluorescent microscopy 


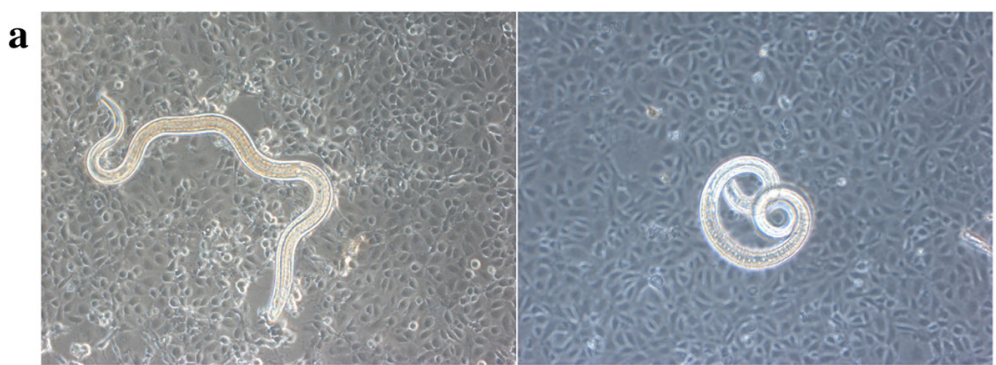

b

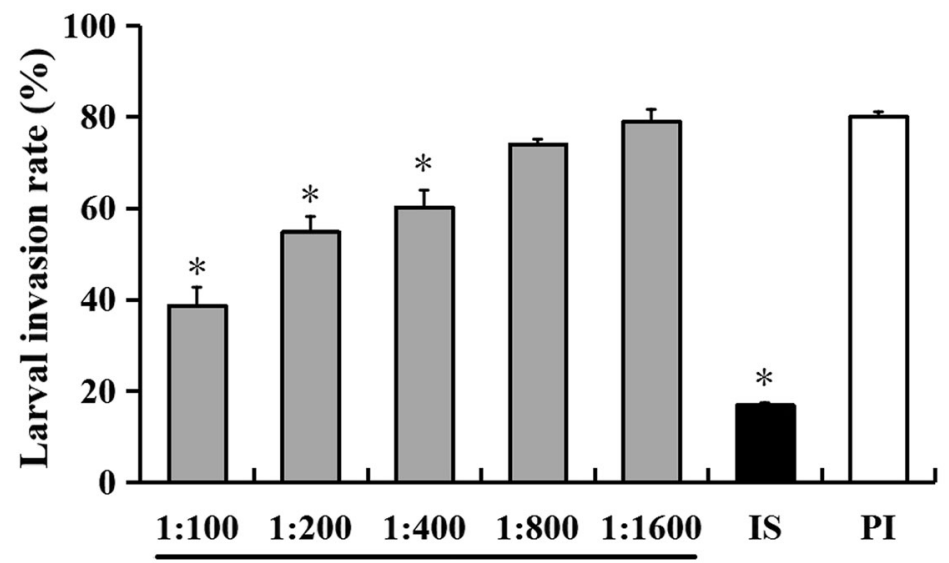

Anti-rTsSPI serum

Fig. 8 The in vitro inhibition of T. spiralis invasion of IEC by anti-rTSSPI serum. a When IEC monolayer was covered and cultured with the semisolid media containing the larvae at $37^{\circ} \mathrm{C}$ for $2 \mathrm{~h}$, the invaded (left) and non-invaded larvae (right) in the IEC monolayer $(\times 200)$. b Inhibition of larval invasion of IEC by different dilutions of anti-rTsSPI serum. The 1:100 dilutions of infection serum (IS) and pre-immune serum (PI) were utilized as control sera. The results are shown as the percent of the larvae invaded the monolayer out of all larvae added into the media. Asterisks indicate statistically significant differences $(P<0.001)$ in comparison with the pre-immune serum group

protein and may play a role in the immunoregulation of T. pseudospiralis infection by directly acting on host's cells or humoral molecules [54]. The TsSPI might inactivate the enzymatic activity by forming a complex with host serine protease, which overlays the surface of Trichinella, and hence protects the worms from the host's serine proteolysis. The protection mechanism could be similar to the one described for Ascaris suum [55].

We identified the protein-protein interactions between rTsSPI and IECs in this study. Far Western analysis revealed that approximate 24 bands of IEC proteins pre-incubated using rTsSPI were identified by the antirTsSPI serum. IIF indicated the rTsSPI specifically bound to intestinal epithelium and IECs, and the location of the binding sites in the IEC membrane and cytoplasm was demonstrated under confocal microscopy. The results indicated that there was an interaction between TsSPI and IECs, and TsSPI might act a major role in parasite invasion of the intestinal epithelium [56]. However, the mechanism of TsSPI and IECs interaction needs to be further studied.

Anti-TsSPI antibodies could inhibit the anti-proteolytic activity of serpins in a way similar to that observed for serpins originating from other parasites, such as $S$. japonicum
[57]. Anti-Trichinella antibodies could bind to T. spiralis surface and form immune complex in the anterior part, which may physically block the worm's recognition and invasion of intestinal mucosa [31, 58]. Our results showed that anti-rTsSPI antibodies could significantly inhibit the larval invasion of IECs and the inhibition was anti-TsSPI antibody dose-dependent. When infection serum was used in the invasion experiment, the inhibition of parasite invasion by infection serum was more obvious than that of the anti-rTsSPI serum. This may be due to the fact that the antibodies to other invasion-related proteins of $T$. spiralis (e.g. glutathione S-transferase, cysteine protease) in infection serum were also involved in inhibition of the invasion $[45,47$, 59, 60]. Previous studies showed the serpins were synthesized mainly in the early developmental stages of the parasites. Schistosoma japonicum serpin is a tegumental protein, and expressed only at cercarial and adult stages; vaccination with the $\mathrm{rSj}$ serpin triggered high levels of specific antibody responses in vaccinated mice and showed partial protection against challenges [57]. The serpin content of Brugia malayi infective stage larvae was 10-16 times higher than those of adults or microfilariae [61]. Our results suggested that TsSPI is 


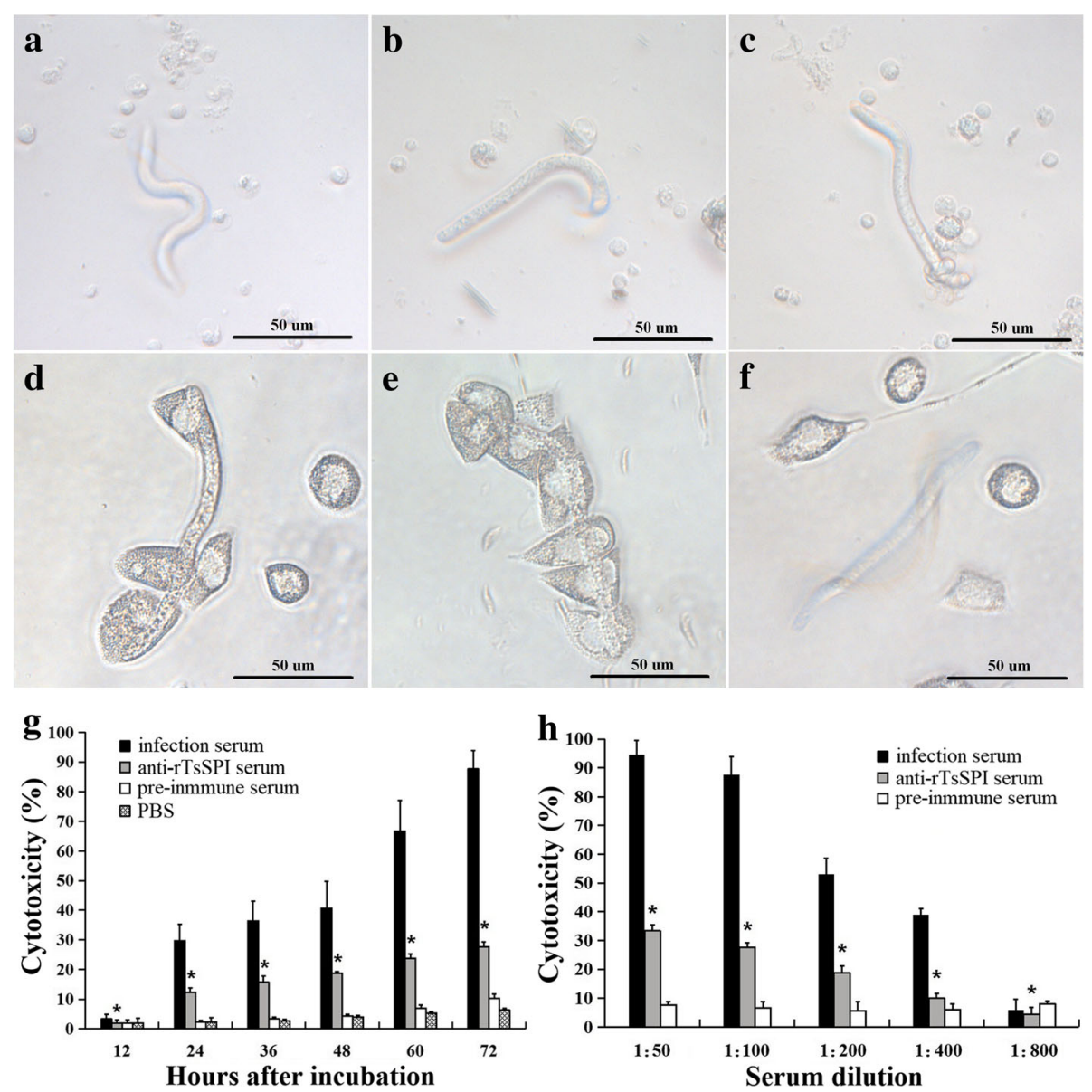

Fig. 9 ADCC killing T. spiralis NBL. a-f Morphology of T. spiralis NBL recovered after ADCC test with different cultivation time periods. The NBL. were cultured using anti-rTsSPI serum and $1 \times 10^{5}$ mouse peritoneal exudate cells (PECs) at $37^{\circ} \mathrm{C}$ for different time periods. a, b No PECs were adhered to NBL $12 \mathrm{~h}$ and $24 \mathrm{~h}$ of cultivation and the NBL was wriggling. $\mathbf{c}$ A few of PECs adhering to NBL $48 \mathrm{~h}$ of cultivation and the NBL was limp with weak activity. $\mathbf{d}$ A dead NBL overlaid with PECs $72 \mathrm{~h}$ of cultivation. Infection serum (e) and pre-immune serum (f) were utilized as control sera. $\mathbf{g}$-h ADCC killing T. spiralis NBL is anti-rTsSPI antibody dose-dependent and associated with culture time. $\mathbf{g}$ The NBL were incubated with same dilution (1:100) of various sera for 12-72 $\mathrm{h}$ of incubation; the cytotoxicity had an increasing trend with the culture time prolongation. $\mathbf{h}$ The NBL were incubated with different sera diluted at 1:50 to 1:800 for 72 h; the cytotoxicity exhibited an anti-rTsSPI antibody dose-dependent pattern. Asterisks indicate that the cytotoxicity of the anti-rTsSPI serum exhibited a significant difference $(P=0.005)$ compared with that of the pre-immune serum

an early invasion-related protein in the process of $T$. spiralis infection.

Previous studies demonstrated that ADCC-mediated destruction of T. spiralis NBL was dependent on specific anti-Trichinella IgG $[62,63]$. Cytotoxicity against NBL in the lungs of T. spiralis-infected mice was found to be IgE-mediated by Falduto et al. [64]. To investigate the cytotoxicity of anti-rTsSPI antibodies, an in vitro ADCC test was also performed in the present study. Our results revealed that anti-rTsSPI antibodies took part in NBL sacrificing. The PECs attached to and destroyed the NBL under the mediation of anti-rTsSPI serum and the destruction was anti-rTsSPI antibody dose dependent. These results demonstrated that TsSPI might participate in Trichinella invasion of the host and it is likely a potential vaccine target molecule against enteral stage worms of $T$. spiralis infection.

\section{Conclusions}

The rTsSPI had the inhibitory activities against porcine trypsin. The rTsSPI especially bound and interacted with host's intestinal epithelium and IECs and the binding sites were located in IEC membrane and cytoplasm. AntirTsSPI antibodies suppressed the T. spiralis invasion of host's IECs in a dose-dependent mode. The TsSPI-specific antibodies also participated in the destruction of T. spiralis NBL via an ADCC-mediated manner. The results demonstrated that TsSPI might participate in the invasion of this nematode in the host, and is likely a potential vaccine target against $T$. spiralis enteral stages. 


\section{Abbreviations}

ADCC: Antibody-dependent cellular cytotoxicity; AW: Adult worms; BAEE: NBenzoyl-DL-arginine ethyl ester hydrochloride; BSA: Bovine serum albumin; DAPI: 4',6-diamidino-2-phenylindole; dpi: Days post-infection; ES: Excretorysecretory; FITC: Fluorescein isothiocyanate; IECs: Intestinal epithelial cells; IIF: Indirect immunofluorescence; IL1: Intestinal first-stage infective larvae; ML: Muscle larvae; NBL: Newborn larvae; PBST: PBS-0.5\% Tween 20; PEC: Peritoneal exudates cells; PI: Propidium iodide; GPCR: Quantitative PCR RCL: Reactive central loop; SD: Standard deviation; serpin: Serine protease inhibitor; TsSPI: T. spiralis serine protease inhibitor

\section{Funding}

This study was supported by grants of the National Natural Science Foundation of China (nos. 81572024, U1704284 and 81672043).

\section{Availability of data and materials}

The data supporting the conclusions of this article are included within the article.

\section{Authors' contributions}

$J C$ and ZQW designed this study. YYS, YZ, HNR, GGS, XQ, FY, PJ and XZ carried out the experiments. YYS, JC and ZQW drafted and revised the manuscript. All authors read and approved the final manuscript.

\section{Ethics approval}

All the animal experiments were authorized by the Zhengzhou University Life Science Ethics Committee (No. SCXK 2015-0005).

\section{Consent for publication}

Not applicable.

\section{Competing interests}

The authors declare that they have no competing interests.

\section{Publisher's Note}

Springer Nature remains neutral with regard to jurisdictional claims in published maps and institutional affiliations.

\section{Received: 16 June 2018 Accepted: 23 August 2018}

\section{Published online: 06 September 2018}

\section{References}

1. Pozio E. The broad spectrum of Trichinella hosts: from cold- to warmblooded animals. Vet Parasitol. 2005;132:3-11.

2. Pozio E. World distribution of Trichinella spp. infections in animals and humans. Vet Parasitol. 2007;149:3-21.

3. Cui J, Wang ZQ Xu BL. The epidemiology of human trichinellosis in China during 2004-2009. Acta Trop. 2011;118:1-5.

4. Jiang $P$, Zhang $X$, Wang $L A$, Han $L H$, Yang M, Duan JY, et al. Survey of Trichinella infection from domestic pigs in the historical endemic areas of Henan Province, central China. Parasitol Res. 2016;115:4707-9.

5. Rostami A, Gamble HR, Dupouy-Camet J, Khazan H, Bruschi F. Meat sources of infection for outbreaks of human trichinellosis. Food Microbiol. 2017;64:65-71.

6. Zhang N, Li W, Fu B. Vaccines against Trichinella spiralis: Progress, challenges and future prospects. Transbound Emerg Dis. 2018; https:// doi.org/10.1111/tbed.12917.

7. Ren HJ, Cui J, Wang ZQ, Liu RD. Normal mouse intestinal epithelial cells as a model for the in vitro invasion of Trichinella spiralis infective larvae. PLoS One. 2011;6:e27010.

8. Despommier DD. Biology. In: Campbell WC, editor. Trichinella and Trichinosis. New York: Plenum Press; 1983. p. 75-151.

9. Liu RD, Wang ZQ, Wang L, Long SR, Ren HJ, Cui J. Analysis of differentially expressed genes of Trichinella spiralis larvae activated by bile and cultured with intestinal epithelial cells using real-time PCR. Parasitol Res. 2013;112:4113-20.

10. Wang ZQ, Liu RD, Sun GG, Song YY, Jiang P, Zhang X, et al. Proteomic analysis of Trichinella spiralis adult worm excretory-secretory proteins recognized by sera of patients with early trichinellosis. Front Microbiol. 2017;8:986.
11. Li LG, Wang ZQ, Liu RD, Yang X, Liu LN, Sun GG, et al. Trichinella spiralis: low vaccine potential of glutathione $S$-transferase against infections in mice. Acta Trop. 2015;146:25-32.

12. Ortega-Pierres G, Vaquero-Vera A, Fonseca-Linan R, Bermudez-Cruz RM, Arguello-Garcia R. Induction of protection in murine experimental models against Trichinella spiralis: an up-to-date review. J Helminthol. 2015;89:526-39.

13. Molehin AJ, Gobert GN, McManus DP. Serine protease inhibitors of parasitic helminths. Parasitology. 2012;139:681-95.

14. Dzik JM. Molecules released by helminth parasites involved in host colonization. Acta Biochim Pol. 2006;53:33-64.

15. Nagano I, Wu Z, Nakada T, Matsuo A, Takahashi Y. Molecular cloning and characterization of a serine proteinase inhibitor from Trichinella spiralis. Parasitology. 2001;123:77-83.

16. Zhang Z, Mao Y, Li D, Zhang Y, Li W, Jia H, et al. High-level expression and characterization of two serine protease inhibitors from Trichinella spiralis. Vet Parasitol. 2016;219:34-9.

17. Xu J, Bai X, Wang LB, Shi HN, van der Giessen JWB, Boireau P, et al. Influence of adjuvant formulation on inducing immune response in mice immunized with a recombinant serpin from Trichinella spiralis. Parasite Immunol. 2017;39:e12437.

18. Mitreva M, Jasmer DP, Zarlenga DS, Wang Z, Abubucker S, Martin J, et al. The draft genome of the parasitic nematode Trichinella spiralis. Nat Genet. 2011:43:228-35.

19. Song $Y Y$, Zhang $Y$, Yang $D Q$, Ren $H N$, Sun $G G$, Liu RD, et al. The immune protection induced by a serine protease inhibitor from Trichinella spiralis. Front Microbiol. 2018;9:1544

20. Gamble HR, Bessonov AS, Cuperlovic K, Gajadhar AA, van Knapen F, Noeckler K, et al. International Commission on Trichinellosis: recommendations on methods for the control of Trichinella in domestic and wild animals intended for human consumption. Vet Parasitol. 2000; 93:393-408

21. Li F, Cui J, Wang ZQ, Jiang P. Sensitivity and optimization of artificial digestion in the inspection of meat for Trichinella spiralis. Foodborne Pathog Dis. 2010;7:879-85

22. Liu RD, Cui J, Liu XL, Jiang P, Sun GG, Zhang X, et al. Comparative proteomic analysis of surface proteins of Trichinella spiralis muscle larvae and intestinal infective larvae. Acta Trop. 2015;150:79-86.

23. Sun GG, Wang ZQ, Liu CY, Jiang P, Liu RD, Wen $H$, et al. Early serodiagnosis of trichinellosis by ELISA using excretory-secretory antigens of Trichinella spiralis adult worms. Parasit Vectors. 2015:8:484.

24. Wu Z, Nagano I, Takahashi Y, Maekawa Y. Practical methods for collecting Trichinella parasites and their excretory-secretory products. Parasitol Int. 2016;65:591-5.

25. Wang L, Cui J, Hu DD, Liu RD, Wang ZQ. Identification of early diagnostic antigens from major excretory-secretory proteins of Trichinella spiralis muscle larvae using immunoproteomics. Parasit Vectors. 2014;7:40.

26. ManWarren T, Gagliardo L, Geyer J, McVay C, Pearce-Kelling S, Appleton J. Invasion of intestinal epithelia in vitro by the parasitic nematode Trichinella spiralis. Infect Immun. 1997:65:4806-12.

27. Wang SW, Wang ZQ, Cui J. Protein change of intestinal epithelial cells induced in vitro by Trichinella spiralis infective larvae. Parasitol Res. 2011;108: 593-9.

28. Bradford MM. A rapid and sensitive method for the quantitation of microgram quantities of protein utilizing the principle of protein-dye binding. Anal Biochem. 1976;72:248-54

29. Liu CY, Song YY, Ren HN, Sun GG, Liu RD, Jiang P, et al. Cloning and expression of a Trichinella spiralis putative glutathione S-transferase and its elicited protective immunity against challenge infections. Parasit Vectors. 2017;10:448.

30. Feng S, Wu X, Wang X, Bai X, Shi H, Tang B, et al. Vaccination of mice with an antigenic serine protease-like protein elicits a protective immune response against Trichinella spiralis infection. J Parasitol. 2013;99:426-32.

31. Wang B, Wang ZQ, Jin J, Ren HJ, Liu LN, Cui J. Cloning, expression and characterization of a Trichinella spiralis serine protease gene encoding a 35.5 kDa protein. Exp Parasitol. 2013;134:148-54.

32. Cui J, Ren HJ, Liu RD, Wang L, Zhang ZF, Wang ZQ. Phage-displayed specific polypeptide antigens induce significant protective immunity against Trichinella spiralis infection in BALB/c mice. Vaccine. 2013:31:1171-7.

33. Wang ZQ, Wang L, Cui J. Proteomic analysis of Trichinella spiralis proteins in intestinal epithelial cells after culture with their larvae by shotgun LC-MS/ MS approach. J Proteome. 2012;75:2375-83. 
34. Merckelbach A, Ruppel A. Biochemical properties of an intracellular serpin from Echinococcus multilocularis. Mol Biochem Parasitol. 2007;156:84-8.

35. Wang L, Wang ZQ, Cui J. Proteomic analysis of the changed proteins of Trichinella spiralis infective larvae after co-culture in vitro with intestinal epithelial cells. Vet Parasitol. 2013;194:160-3.

36. Teixeira AV, Dowdle EB, Botes DP. Synthesis and expression of a gene coding for Erythrina trypsin inhibitor (ETI). Biochim Biophys Acta. 1994;1217:16-22.

37. Garcia VA, Freire M, Novello JC, Marangoni S, Macedo ML. Trypsin inhibitor from Poecilanthe parviflora seeds: purification, characterization, and activity against pest proteases. Protein J. 2004;23:343-50.

38. Sun GG, Song YY, Jiang P, Ren HN, Yan SW, Han Y, et al. Characterization of a Trichinella spiralis putative serine protease. Study of its potential as serodiagnostic tool. PLoS Negl Trop Dis. 2018;12:e0006485.

39. Long SR, Wang ZQ, Jiang P, Liu RD, Qi X, Liu P, et al. Characterization and functional analysis of Trichinella spiralis Nudix hydrolase. Exp Parasitol. 2015;159:264-73.

40. Liu RD, Qi X, Sun GG, Jiang P, Zhang X, Wang LA, et al. Proteomic analysis of Trichinella spiralis adult worm excretory-secretory proteins recognized by early infection sera. Vet Parasitol. 2016;231:43-6.

41. Wang L, Wang ZQ, Cui J. Protein changes in Trichinella spiralis muscle larvae in vitro induced by bovine bile. Vet Parasitol. 2013;194:164-7.

42. Yang W, Li LG, Liu RD, Sun GG, Liu CY, Zhang SB, et al. Molecular identification and characterization of Trichinella spiralis proteasome subunit beta type-7. Parasit Vectors. 2015;8:18.

43. Cui J, Wang L, Sun GG, Liu LN, Zhang SB, Liu RD, et al. Characterization of a Trichinella spiralis $31 \mathrm{kDa}$ protein and its potential application for the serodiagnosis of trichinellosis. Acta Trop. 2015;142:57-63.

44. Zhang Y, Wang Z, Li L, Cui J. Molecular characterization of Trichinella spiralis aminopeptidase and its potential as a novel vaccine candidate antigen against trichinellosis in BALB/C mice. Parasit Vectors. 2013;6:246.

45. Liu CY, Ren HN, Song YY, Sun GG, Liu RD, Jiang P, et al. Characterization of a putative glutathione S-transferase of the parasitic nematode Trichinella spiralis. Exp Parasitol. 2018;187:59-66.

46. Gagliardo LF, McVay CS, Appleton JA. Molting, ecdysis, and reproduction of Trichinella spiralis are supported in vitro by intestinal epithelial cells. Infect Immun. 2002:70:1853-9.

47. Cui J, Li LG, Jiang P, Liu RD, Yang X, Liu LN, et al. Biochemical and functional characterization of the glutathione S-transferase from Trichinella spiralis. Parasitol Res. 2015;114:2007-13.

48. Zhang SB, Jiang P, Wang ZQ, Long SR, Liu RD, Zhang X, et al. DsRNAmediated silencing of Nudix hydrolase in Trichinella spiralis inhibits the larval invasion and survival in mice. Exp Parasitol. 2016;162:35-42.

49. Liu LN, Wang ZQ, Zhang X, Jiang P, Qi X, Liu RD, et al. Characterization of Spirometra erinaceieuropaei plerocercoid cysteine protease and potential application for serodiagnosis of sparganosis. PLoS Negl Trop Dis. 2015;9:e0003807.

50. Moskwa B. Trichinella spiralis: in vitro cytotoxicity of peritoneal cells against synchronous newborn larvae of different age. Parasitol Res. 1999:85:59-63.

51. Jiang $P$, Wang ZQ, Cui J, Zhang X. Comparison of artificial digestion and Baermann's methods for detection of Trichinella spiralis pre-encapsulated larvae in muscles with low-level infections. Foodborne Pathog Dis. 2012;9: $27-31$.

52. Jin X, Deng L, Li H, Zhang Z, He Q, Yang C, et al. Identification and characterization of a serine protease inhibitor with two trypsin inhibitor-like domains from the human hookworm Ancylostoma duodenale. Parasitol Res. 2011;108:287-95

53. Blanton RE, Licate LS, Aman RA. Characterization of a native and recombinant Schistosoma haematobium serine protease inhibitor gene product. Mol Biochem Parasitol. 1994:63:1-11.

54. Xu N, Liu X, Tang B, Wang L, Shi HN, Boireau P, et al. Recombinant Trichinella pseudospiralis serine protease inhibitors alter macrophage polarization in vitro. Front Microbiol. 2017;8:1834.

55. Martzen MR, Geise GL, Hogan BJ, Peanasky RJ. Ascaris suum: localization by immunochemical and fluorescent probes of host proteases and parasite proteinase inhibitors in cross-sections. Exp Parasitol. 1985;60:139-49.

56. Butcher BA, Gagliardo LF, ManWarren T, Appleton JA. Larvae-induced plasma membrane wounds and glycoprotein deposition are insufficient for Trichinella spiralis invasion of epithelial cells. Mol Biochem Parasitol. 2000; 107:207-18
57. Yan Y, Liu S, Song G, Xu Y, Dissous C. Characterization of a novel vaccine candidate and serine proteinase inhibitor from Schistosoma japonicum (Sj serpin). Vet Parasitol. 2005;131:53-60.

58. McVay CS, Bracken P, Gagliardo LF, Appleton J. Antibodies to tyvelose exhibit multiple modes of interference with the epithelial niche of Trichinella spiralis. Infect Immun. 2000;68:1912-8.

59. Song YY, Wang LA, Ren HN, Qi X, Sun GG, Liu RD, et al. Cloning, expression and characterization of a cysteine protease from Trichinella spiralis. Folia Parasitol. 2018:65:007.

60. McVay CS, Tsung A, Appleton J. Participation of parasite surface glycoproteins in antibody-mediated protection of epithelial cells against Trichinella spiralis. Infect Immun. 1998;66:1941-5.

61. Yenbutr P, Scott AL. Molecular cloning of a serine proteinase inhibitor from Brugia malayi. Infect Immun. 1995;63:1745-53.

62. Kazura JW. Host defense mechanisms against nematode parasites: destruction of newborn Trichinella spiralis larvae by human antibodies and granulocytes. J Infect Dis. 1981;143:712-8.

63. Sun GG, Ren HN, Liu RD, Song YY, Qi X, Hu CX, et al. Molecular characterization of a putative serine protease from Trichinella spiralis and its elicited immune protection. Vet Res. 2018:49:59.

64. Falduto GH, Vila CC, Saracino MP, Calcagno MA, Venturiello SM. Trichinella spiralis: killing of newborn larvae by lung cells. Parasitol Res. 2015;114:679-85.

\section{Ready to submit your research? Choose BMC and benefit from:}

- fast, convenient online submission

- thorough peer review by experienced researchers in your field

- rapid publication on acceptance

- support for research data, including large and complex data types

- gold Open Access which fosters wider collaboration and increased citations

- maximum visibility for your research: over $100 \mathrm{M}$ website views per year

At $\mathrm{BMC}$, research is always in progress.

Learn more biomedcentral.com/submissions 